\title{
Sustainable blends of LDPE/NR and sugarcane bagasse ashes with PE-g-MA thermomechanical relationships
}

\author{
Misturas sosteniveis de PEBD/BN e cinzas \\ de bagaço da cana de açúcar Com PE-g- \\ AM relações termomecânicas
}

\author{
Giovanni Barrera Torres ${ }^{1}$, Guilherme Dognani ${ }^{2}$, Flávio Camargo Cabrera ${ }^{2}$, \\ Júlio Cézar Alzate ${ }^{3}$, José Alexandrino de Souza ${ }^{3}$, \\ Elton Prado dos Reis ${ }^{2}$, Silvio Rainho Teixeira ${ }^{2}$, \\ Aldo Eloizo Job ${ }^{2}$
}

\footnotetext{
${ }^{1}$ Departamento de desenho industrial, FA y H. Instituto Tecnológico Metropolitano, Medellín, Antioquia, Colombia.

${ }^{2}$ Departamento de Física, FCT/UNESP, Laboratório de Tecnologia de Borrachas e Aplicações, São Paulo, São Paulo, Brasil.

${ }^{3}$ Departamento de Engenharia de Materiais Universidade Federal de São Carlos, São Carlos, São Paulo, Brasil.

e-mail: job@fct.unesp.br, giovannibarrera@itm.edu.co
}

\section{ABSTRACT}

The polymer blends obtained with residues that before were called wastes has been growing as a viable solution, allowing improvements in the mechanical properties and as sustainable alternative. This work reports the effects of blends of low-density polyethylene (LDPE) and natural rubber (NR), with sugar cane bagasse ash (SCBA) as filler, with and without polyethylene-graft-maleic anhydride (PE-g-MA) how coupling agent. The dynamic mechanical behavior and a stress-strain analysis were studied. The materials were further evaluated by differential scanning calorimetry and morphological observations. The results showed that incorporation of the PE-g-MA reduced the strain and improved the stress and the Young module of the mixtures. Moreover, the presence of SCBA increased the hardness while maintaining the tensile strength and the elongation behavior of the polymer. The results demonstrate the potential use of SCBA in the elastomer and thermoplastic mixture, free of vulcanization agents.

Keywords: Sustainable blends, sugarcane bagasse ashes, natural rubber, low density polyethylene, polyethylene-graft-maleic anhydride.

\section{RESUMO}

As blendas poliméricas obtidas com resíduos que antes eram chamados de lixos vêm crescendo como uma solução viável, permitindo melhorias nas propriedades mecânicas e como alternativas sustentáveis. Este trabalho relata os efeitos de misturas de polietileno de baixa densidade (PEBD) e borracha natural (NR), com cinzas de bagaço de cana-de-açúcar (CBCA) como carga, com e sem polietileno-enxertado com anidrido maleico (PE-g-MA) como agente de ligação. Os comportamentos dinâmico-mecânico e a análise de tensão-deformação foram estudados. Os materiais foram avaliados por calorimetria diferencial de varredura e observações morfológicas. Os resultados mostraram que a incorporação do PE-g-MA reduziu a deformação e melhorou o estresse e o módulo Young das misturas. Além disso, a presença de SCBA aumentou a dureza, mantendo a resistência à tração e o comportamento de alongamento do polímero. Os resultados demonstram o potencial uso da CBCA na mistura de elastômeros e termoplásticos, livres de agentes de vulcanização.

Palavras-chave: Misturas sustentáveis, cinzas de bagaço de cana-de-açúcar, borracha natural, polietileno de baixa densidade, polietileno-enxertado com anidrido maleico.

\section{INTRODUCTION}

Advances in the polymer industry have allowed the development of new environmentally friendly, recyclable composites [1]. Thermoplastic elastomers (TPE) have the processing characteristics of a thermoplastic material and the functional properties of an elastomer, in addition to high recyclability [2]. 
The elastomers thermoplastics consists of both rigid and flexible areas, which can be copolymers [3] or polymer blends [4,5]. In these materials, the elastomer contributes to improved impact resistance and increased ductility. Among the thermoplastics one of the most used in the world industry is the (LDPE), this polymer has a crystallinity between 40 and 50\%[6] and has unique rheological properties compared to linear and high density PE due to its long branched chains that directly influence crystallinity.

The LDPE is used in the industry of packaging, toys, household utensils, medical equipment, to insulation for threads, among others [7]. For this reason, is necessary to know their behavior in mixtures with natural residues and natural rubber and to know the influence of these in the physical properties mechanics, focused to contribute to reduze the negative impact during their industrial applications. On the other hand, the ash from sugarcane bagasse (SCBA) is a waste residue obtained from the burning of bagasse in the sugar industry, the production has increased annually with the sector's grown [8-10].

The cane bagasse produced is combusted to generate power for use in the industry itself, while the resulting ashes are discarded to landfills or utilized as fertilizer in sugarcane plantations, leading to a serious environmental problem [10]. The main component of SCBA is silica [12-14], which allows the potential use of this waste as reinforcement in different elastomer materials or thermoplastics [15-17]. As an additional feature to improve the dispersion and interaction between the SCBA and the matrix $[18,19]$ polyethylene-grafted with maleic anhydride (PE-g-AM) can be used as a "coupling agent [20,21]. This work reports the evaluation of (LDPE)/(NR-SCBA) and (PE-g-AM) mixtures of their mechanical and morphological properties sulfur free usually used in the rubber industry.

\section{MATERIALS AND METHODS}

The SCBA was provided by the Sugar Cane Plant Alto Alegre, Santo Inácio City-PR, Brazil. The particle size of the ash was chosen as $44-125 \mu \mathrm{m}$ was selected. The melting points were experimentally obtained, for the LDPE $115 \pm 4{ }^{\circ} \mathrm{C}$ and the polyethylene-graft-maleic anhydride (PE-g-MA) was $107 \pm 2{ }^{\circ} \mathrm{C}$. The dry natural rubber (NR) of the commercial variety CCB (Crepe Claro Brasilero) financed by the DLP industria e comercio de Borracha e Artefatos(R) in the city of Polony/SP/Brazil. This NR or cis-1,4polyisoprene was obtained in processing plants by the coagulation of latex from Hevea brasiliensis species, clones RRIM 600 while the LDPE and the PE-g-MA were supplied by Sigma Aldrich/Brazil.

\subsection{Manufacture of blends}

The first step was the elaboration of the mixture between NR and SCBA which is called the master. For the production of the master, the NR and SCBA were mixed in an open chamber mixer (Makintec brand model $379 \mathrm{~m}$ ) during $20 \mathrm{~min}$. at $70{ }^{\circ} \mathrm{C}$ and friction 1.0:1.25 for 15 min to obtain a homogeneous mass for next step with the LDPE mixture in the Haake rheometer process, explained below.

\subsection{Rheology}

The master was mixed with LDPE in a Haake rheometer equipped with a rotor type Roller to obtain a LDPE/master composite. The LDPE/master blends were produced in ratios of 90/10 wt. $\%, 70 / 30 \mathrm{wt} . \%$ and 50/50 wt.\%, with $25 \mathrm{wt} . \%$ SCBA. A second series of blends was also prepared in the above ratios, with addition of $2.5 \mathrm{wt} . \%$ PE-g-MA. The mixing was carried out at $40 \mathrm{rpm}$ and $125{ }^{\circ} \mathrm{C}$ for $10 \mathrm{~min}$. in the Haake torque rheometer, with a subsequent pressing temperature of $150{ }^{\circ} \mathrm{C}$ for $4 \mathrm{~min}$. these ratios were chosen with the aim of evaluating the effect of the PE-g-MA in the blend systems over a compositions with NR and SCBA mixed with high proportions of LDPE conditioned for the maximun volume in the rheometer mixture chamber $(45 \mathrm{~g})$.

These conditions were selected on the basis of previous experimental data and reports from the literature [22-24]. In the first step (minute one) was added the LDPE into the Haake mixture chamber, subsequently was added the NR in the second minute of rotors rotation; this process was maintained for a time of 10 minutes, until observing the continuity in the reometry curve, indicating torque equilibrium.

\subsection{Compression molding}

The material was molded using a hydraulic press with an applied pressure of $5 \mathrm{MPa}$ at a temperature of $150{ }^{\circ} \mathrm{C}$ for 6 min. using rectangular plates with internal dimensions of $150 \mathrm{~mm} \times 110 \mathrm{~mm} \times 2 \mathrm{~mm}$. The cooling process was at room temperature in the same metallic plates. After, the samples were conserved for two days before cut the form suggered in the ASTM D 412 norm, for the stress-strain evaluation. In the Figure 1 is show the steps with which was obtained the blends. 


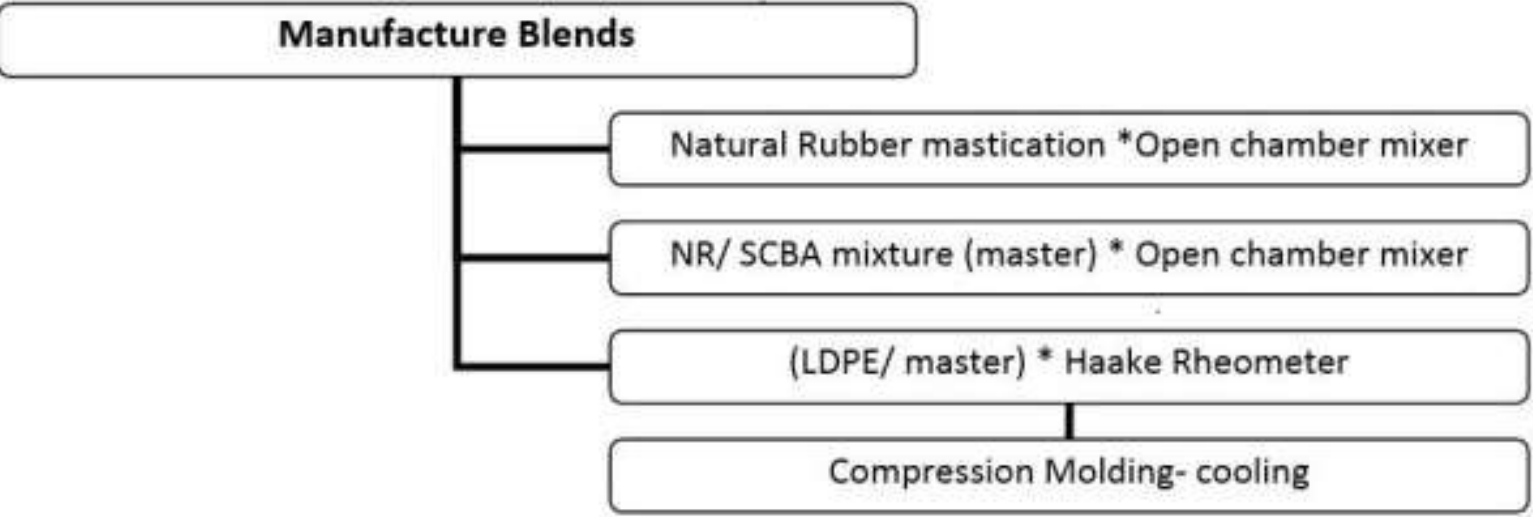

Figure 1: Process of obtaining mixtures.

\subsection{Characterization}

Morphological studies were carried out on a cross-sectional samples prepared using a cryogenic break with and without PE-g-MA. Analyses were performed by scanning electron microscopy to evaluate the interaction between the constituents in terms of the morphology, homogeneity, and dispersion of the particles in the developed matrix[25]. The scanning electron microscope used was the Carls Zeiss EVO model LS15, with a secondary electron (SE) detector. The samples measurements were performed directly on the metalized surfaces (sputter-coated with gold) first of the samples superficial faces and next of the cryogenical fractured surface obtained.

The tensile test were conducted on a Essays universal machine EMIC, model DL 2000. The stressstrain test were carried out in accordance with the ASTM D 412 norm, using tie beakers type C; for the analysis was used a $100 \mathrm{~N}$ load cell and $500 \mathrm{~mm} / \mathrm{min}$ cross-head speed. Tensile strength and modulus values correspond to the average of three samples. The average standard deviation attached to the measurements is it's below $10 \%$.

The hardness test were carried out in accordance with the Shore A, ASTM D 2240 norm. This method consists of forcing a penetrator on the test body, the analysis was made using a Portable hardness tester reference PCE-DX-AS of PCE instruments. The resulting in a lower value the greater the depth reached. The Shore A scale is directly related to the elastic modulus of the penetrator material. The test was performed with triple repetition on the three samples for mixture, according to the referred norm; the average standard deviation derived of the repetions attached to the measurements is lower than $10 \%$.

The DMA was performed using NETZSCH 242C model 242C interface TASC 414/3A and controller 242 with $5.0 \mathrm{~Hz}$ frequency, in the temperature range of -120 to $150{ }^{\circ} \mathrm{C}$ and at a heating rate of 5 ${ }^{\circ} \mathrm{C} / \mathrm{min}$, maximum dynamic force of $5.0 \mathrm{~N}$, and static force of $1.5 \mathrm{~N}$, in the three-point mode. The cooling process was carried out in $\mathrm{N} 2$ atmosphere. The average dimensions of the samples were $11 \mathrm{~mm}$ length, $5.0 \mathrm{~mm}$ width and $1.5 \mathrm{~mm}$ thickness. All characterizations were performed after compression molding process, implemented to blends for the laboratório de tecnología de borrachas e applicações (LTBA), Presidente Prudente, SP-Brazil for the research in elastomers thermoplastics line.

The differential scanning calorimetry (DSC). In the thermal analysis measurements of the selected systems were performed by using a Perkin Elmer SC-7 analyzer. Samples of approximately $8 \mathrm{mg}$ were heated from $25{ }^{\circ} \mathrm{C}$ to $250{ }^{\circ} \mathrm{C}$ by using of nitrogen flow of $100 \mathrm{~mL} / \mathrm{min}$ and a heating rate of $10{ }^{\circ} \mathrm{C} / \mathrm{min}$. The cristallinity of the selected mixtures were determined by using of the following relationship:

$$
\begin{aligned}
& X \boldsymbol{c}=\frac{(\Delta H \mathrm{~m})}{(\Delta H \mathrm{mc})} \times 100 \\
& X \boldsymbol{c}=\frac{(\Delta H \mathrm{~m})}{(\mathrm{Hmp})(\Delta \mathrm{Hmc})} \times 100
\end{aligned}
$$


For the calculation of the crystallinity $(\mathrm{Xc})$, the melting enthalpy value of the polyethylene with the crystallinity obtained from the literature in this case $290 \mathrm{~J} / \mathrm{g}$ [26] was considered. The enthalpy values of the samples were obtained from the DSC curves of the same ones, being the determination of the value done by means of the software Proteus ${ }^{\circledR}$. Calculation of crystallinity $(\mathrm{Xc})$ for LDPE was performed using Equation (01) and for the mixtures was used the Eq. 02 . Where $\Delta \mathrm{Hm}$ and $\Delta \mathrm{Hmc}$ are respectively, the fusion enthalpy values of the sample and enthalpy of the fully crystalline LDPE, (\% mp) is the value of the proportion of the semicrystalline material present in the compound. The calculation of the crystallinity was made using the equation 01 , where it was necessary to take the data of the specific heat $(\mathrm{J} / \mathrm{g})$ of the samples, the values were obtained following the ASTM D 3417 standard.

\section{RESULTS AND DISCUSSION}

\subsection{Haake rheology}

Figure 2 shows the curves for the rheological behavior of the LDPE/master blends without the PE-g-MA. The highest torque $(21 \mathrm{Nm})$ was observed for the 90/10 (wt.\%) sample, because of the high energy requirement for the equipment to disentangle and shear the LDPE chains before they were mixed with the master. At instant of mixing the torque decreased to approximately $11 \mathrm{Nm}$. This result was obtained by the amount of polyethylene in the mixture that directed the behavior of the torque in the equipment. Second, equilibrium torque values were measured. A value of $13 \mathrm{Nm}$ was recorded for the 90/10 (wt.\%) mixture. For the masses $70 / 30(\% \mathrm{w})$ and $50 / 50(\% \mathrm{w})$ the behavior showed in the graphical curves was similar, reaching $8 \pm 0.2 \mathrm{Nm}$ until the interruption of the mixture. The increase in torque is part of the interaction process between the constituent materials, whose blends delivered better performance in the stress-strain analyses because of the superior interface between the matrix and the SCBA particle system. This behavior has also been reported in the literature [27,28].

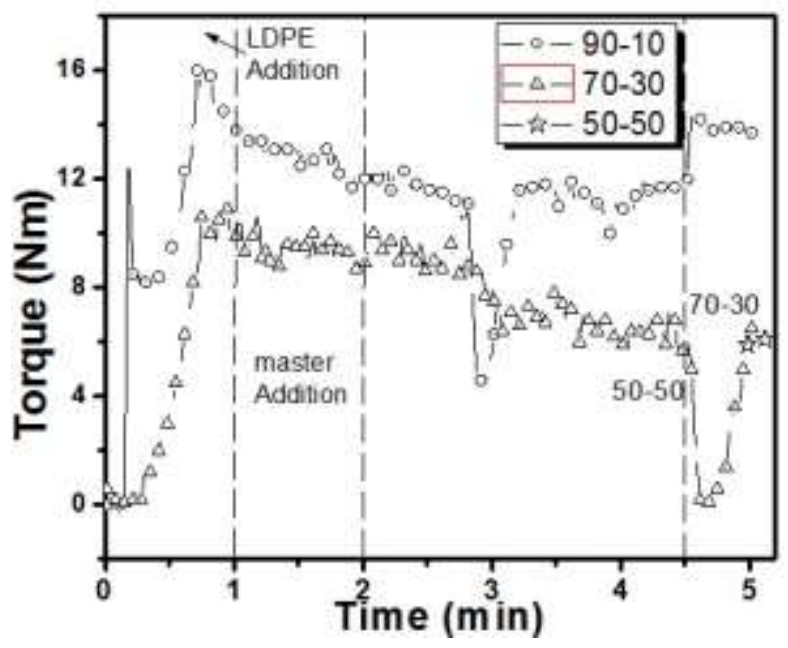

Figure 2: Haake rheometry curves of the blends (LDPE/master).

The Figure 3 shows the curves of the LDPE/master-PE-g-MA mixture. A torque of $16 \mathrm{Nm}$ was observed for the 90/10 (wt.\%) mixture while that for the 70/30 (wt.\%) and 50/50 (wt.\%) samples reached $9 \mathrm{Nm}$. Equilibrium torque values of $13 \mathrm{Nm}, 7 \mathrm{Nm}$ and $7 \mathrm{Nm}$ were recorded for the 90/10 (wt.\%), 70/30 (wt.\%), and 50/50 (wt.\%) samples, respectively. With the melting of the material, the torque was stabilized, which indicated the final step of interaction between the constituents. 


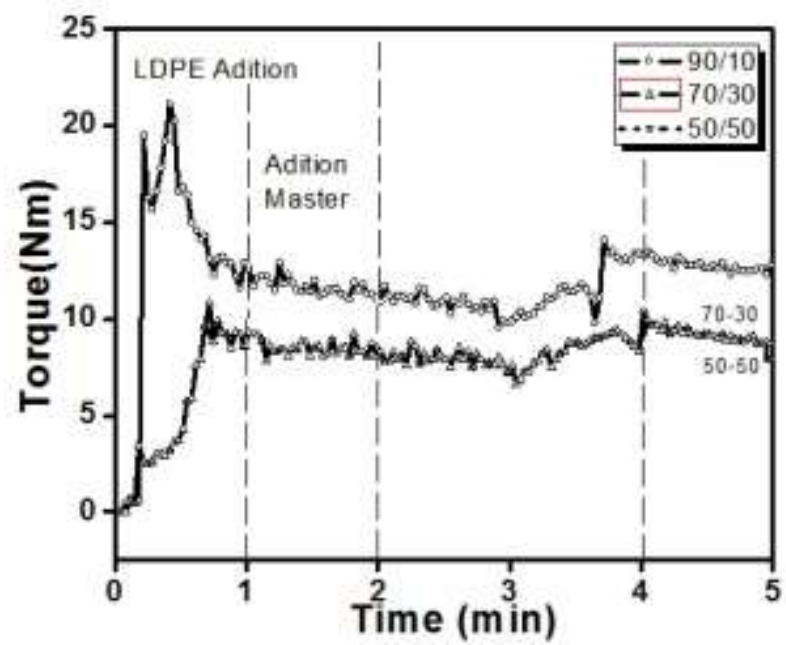

Figure 3: Haake rheometry curves of (LDPE /master)-PE-g-MA blends.

\subsection{Stress-strain behavior}

The Figure 4 displays the results of the stress-strain analyses of the mixtures with NR-LDPE without SCBA or vulcanization agents. The highest tensile strength response was observed for the 90/10 (wt.\%) sample. The curve showed a characteristic thermoplastic behavior, with a region of the linear elastic zone reaching almost 8.5 MPa at the limit of flow and breaking with $40 \%$ elongation.

It could be concluded that the tensile strength and elongation behavior up to the rupture point for the LDPE used showed an expected behavior. However, with the addition of NR in $30 \%$ and $50 \%$ of the total mass of the mixture, the response capacity was lost due to the low level of adhesion and entanglement between the amorphous chains of the NR and LDPE. This was attributed to the lack of a third element, the so-called compatibilizer, which results in the formation of binding sites that facilitate the entanglement of the chains in the mixture. The behavior of the LDPE pure was similar until the yield limit was reached at the end of the linear behavior at 4.5 MPa, while the other samples showed a yield point below this limit. The prepared samples presented superior deformation properties, with almost $72 \%$ deformation for the $90 / 10$ and $31 \%$ deformation for 70/30 (wt.\%) blends. The 50/50 (wt.\%) sample gave a low elongation of $26 \%$.

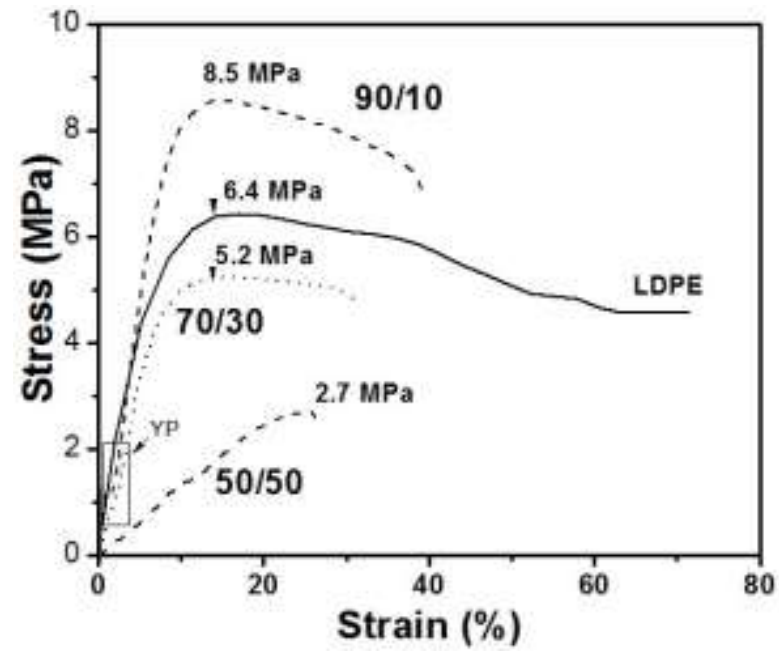

Figure 4: Curves of stress-strain behavior of LDPE/NR.

The deformation behavior of the LDPE/master blends without a compatibilizing agent is illustrated in Figure 5. It can be observed that the curves for the 70/30 (wt.\%) sample showed the best strain behavior. In the stress test, an elongation of $31 \%$ was obtained over the initial length of the specimen until rupture, which indicated a tensile strength of 5.24 MPa. The curves obtained from the 50/50 (wt.\%) sample presented an elongation of $28 \%$ over the initial length of the specimen and a tensile strength of $2.76 \mathrm{MPa}$. The result for the 90/10 (wt.\%) sample showed an elongation of $38 \%$ and a resistance of $8.57 \mathrm{MPa}$. 


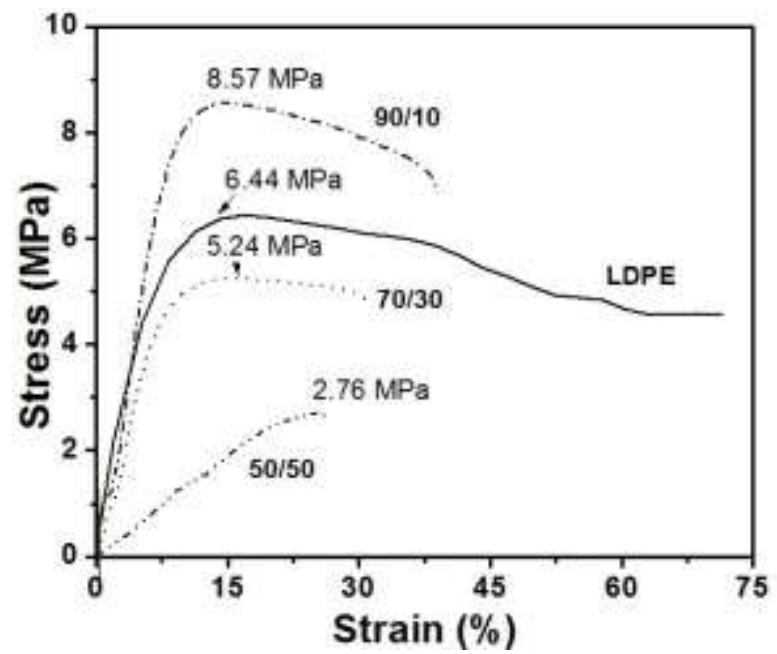

Figure 5: Curves of stress-strain behavior of LDPE/master.

From the calculated results, it was seen that the 90/10 (wt.\%) sample had the highest modulus at $69 \mathrm{MPa}$. The second highest modulus was observed for the 70/30 (wt.\%) sample at $66 \mathrm{MPa}$, and the lowest value was observed for the 50/50 (wt.\%) sample at $24 \mathrm{MPa}$. Thus, it was proven that the predominance for the responses is directly proportional to the percentage of LDPE in the samples and to the attraction between the polymer chains, which causes an increase in the torque during Haake rheometry.

The Figure 6 shows the deformation curves of the LDPE/master-PE-g-AM blends. The curves for the $90 / 10$ and 50/50 (wt.\%) samples presented the best deformation behavior and resistance to rupture, with elongations of $28 \%$ and $23 \%$ and tensile strengths of 7.6 MPa and 2.7 MPa, respectively. For the $70 / 30$ (wt.\%) sample, the elongation to rupture and tensile strength were $17 \%$ and $5.96 \mathrm{MPa}$, respectively. The yield point was observed below the $2 \mathrm{MPa}$ limit, show deformation earlier, but a good resistance without using reticulation systems.

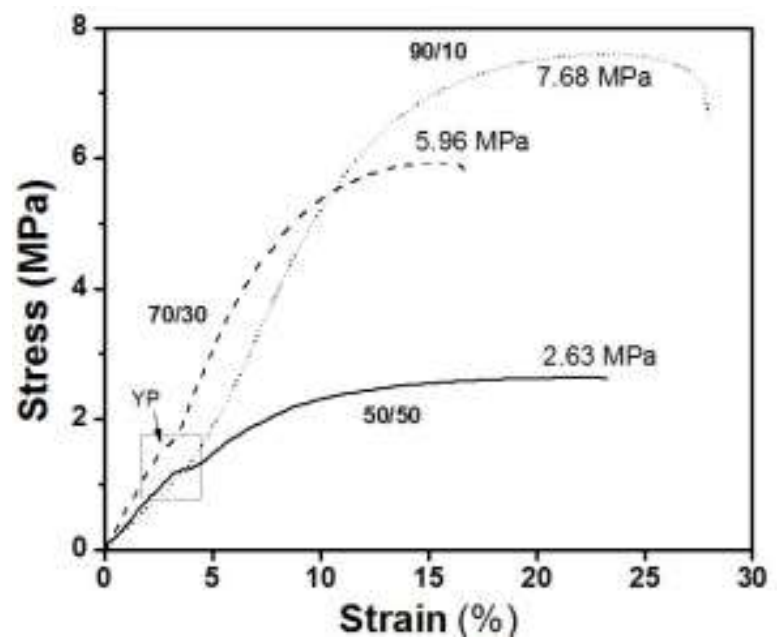

Figure 6: Curves of stress-strain behavior of LDPE/ (master)-PE-g-MA.

The deformation curves revealed that the yield points reached in the samples with the graphitized agent were characteristic of an elastomeric phase; the behavior was more elastic than plastic as compared to that of the pure samples, shown in Figure 4. Table 01 compares the values for the samples used in this study.

The data showed that the tensile strength of polyethylene increased upon mixing with 10 and 30 (wt.\%) NR, but the elongation decreased in proportion to the increase in NR content. This behavior is attributed to the poor interaction between the semi-crystalline chains of the LDPE and the amorphous 
chains of the NR, so that high coupling levels were not achieved. The degree of coupling may be optimized using cross-linking agents such as peroxides and silanes[29-31]. The data for the blends of LDPE/master with PE-g-MA demonstrated that the tensile strength was improved in the presence of 30 and 10 (wt.\%) NR in the mixtures containing the graphitized agent and maintained a behavior against elongation with similar results.

The modulus of elasticity (E) for the blends was lower than that for the master NR-SCBA. As an exception, the modulus of elasticity was higher for the mixture with 50 (wt.\%) NR, because of the optimized interaction between the amorphous branches of the LDPE chains and the amorphous phase on the chains of the NR. The samples with the highest proportion of NR melted and presented uniform rheological behavior in the final stage of the mixing process in the Haake tests.

The results for the samples containing PE-g-MA demonstrated that it is necessary to optimize the coupling interaction between the component materials, with the application of an peroxide to start the process of formation of free radicals with which the mechanical performance of the mix, although the values obtained are functional for the development of products in the industry, comparing the results with mixtures of PE and natural fibers [32,33].

Table 1: Stress-Strain Results.

\begin{tabular}{|c|c|c|c|c|}
\hline Samples & (wt \%) & $\begin{array}{c}\text { Stress } \\
\text { (MPa) } \\
\pm 4\end{array}$ & $\begin{array}{l}\text { Strain } \\
(\%) \pm 4\end{array}$ & $\begin{array}{c}\text { Module E } \\
(\mathrm{MPa}) \pm 3\end{array}$ \\
\hline LDPE & 100 & 6.4 & 72 & 105 \\
\hline \multirow{3}{*}{ LDPE/NR } & $90 / 10$ & 8.5 & 39 & 42 \\
\hline & $70 / 30$ & 5.2 & 31 & 26 \\
\hline & $50 / 50$ & 2.7 & 26 & 23 \\
\hline \multirow{3}{*}{$\begin{array}{c}\text { B) } \\
\text { PEBD/(master) }\end{array}$} & $90 / 10$ & 7.4 & 30 & 38 \\
\hline & $70 / 30$ & 5.4 & 55 & 35 \\
\hline & $50 / 50$ & 2.3 & 40 & 33 \\
\hline \multirow{3}{*}{$\begin{array}{c}\text { PEBD/(master) } \\
\text { PE-g-MA }\end{array}$} & $90 / 10$ & 7.6 & 28 & 69 \\
\hline & 70/30 & 5.9 & 17 & 59 \\
\hline & $50 / 50$ & 2.6 & 23 & 32 \\
\hline
\end{tabular}

\subsection{Shore A hardness}

The hardness of the composites is influenced by the interaction between the polymer chains of the constituents in the samples, which also affects the rheological properties as the elasticity modulus is related to the stiffness caused by the SCBA particles in the polymer. The greater the resulting value, the greater the hardness, therefore, the stiffness of the material. This factor contributes significantly to the mechanical properties of the blend. Table 2 shows that the composites with 90 (wt.\%) LDPE and 10 (wt.\%) master have the highest Shore A hardness.

Table 2: Shore A hardness

\begin{tabular}{llll}
\hline \multicolumn{1}{c}{ Samples } & \multicolumn{3}{c}{ Hardness Shore A ( $\mathbf{2}$ ) } \\
\hline \hline $\begin{array}{l}\text { Total weight } \\
\text { percentage (\%wt) }\end{array}$ & $\mathbf{9 0 / 1 0}$ & $\mathbf{7 0 / 3 0}$ & $\mathbf{5 0 / 5 0}$ \\
& & & \\
LDPE/(master) & 92 & 92 & 82 \\
\hline
\end{tabular}


The most significant increase in hardness upon the addition of SCBA to the samples was observed on the misture with PE-g-MA, which could be attributed to the optimization between the matrix and the SCBA interaction. The blends presented similar results in the hardness study as the 70/30 (wt.\%) sample. The 90/10 (wt.\%) sample was superior in hardness to the other mixtures studied. These trends result from the good interaction between the SCBA particles present in the master with the LDPE.

From the results, it can be concluded that the materials developed in this study are industrially attractive for the development of shock absorbers, among other products. According to information provided by the Apiplast Pessin $\bigodot$ Group, which manufactures and supplies thermoplastic elastomers for industry in general, such as TPO Compounds bathroom fixtures APIGO P BIO PM 120®, the Shore A hardness can range from 50 to 90 and resistance the traction of $6.3 \mathrm{MPa}$; depending on the application in which the materials are $100 \%$ reprocessable [34]. It can be concluded that the material developed up to this stage is industrially attractive for products that do not require high mechanical stresses, above $5 \mathrm{MPa}$, among these, products for use in the home.

\subsection{Differential scanning calorimetry}

In this section, we discuss the curves for the manufactured blends and the individual parent materials. The results presented in Figure 7 verify that the glass transition of natural rubber occurs at $-60{ }^{\circ} \mathrm{C}$, which is similar to $\mathrm{Tg}$ values reported in the literature. The curve obtained for the SCBA is linear due to the amount of silica present in the sample and shows the expected behavior up to $900{ }^{\circ} \mathrm{C}$, owing to the high thermal resistance of the SCBA. For the LDPE with PE-g-MA, a first-order transition at $115{ }^{\circ} \mathrm{C}$ is recorded due to the melting of the material, which correlates with the results of rheometry analysis.

The observed peak width relates to the transition, which in turn is dependent on the wide distribution of molar mass within the sample due to branching and the distribution and size variation of the crystals [35]. For other side, were identified the crystallinity values for the 70/30 mistures, due to the target of the exploration was identify the properties in percentage greater than $50 \%$ of NR. For the calculation of the crystallinity $(\mathrm{Xc})$, the melting enthalpy value of the polyethylene with the crystallinity obtained from the literature was considered. The enthalpy values of the samples were obtained from the DSC curves of the same ones, being the determination of calculation of crystallinity (Xc) for LDPE was performed using Equations (01 and 02) showed item 2.4. The values were organized in Table 3.

Table 3: Crystallinity values.

\begin{tabular}{c||cc}
\hline \hline \multicolumn{1}{c||}{ Samples } & $\Delta \mathrm{Hm}(\mathbf{J} / \mathbf{g})$ & $\mathrm{Xc}(\%)$ \\
\hline LDPE & 75 & 26 \\
\hline LDPE/(master)-PE-g-MA 70/30 (\%wt) & 45 & 15 \\
\hline LDPE/(master)70/30 (wt\%) & 44 & 15 \\
\hline \hline
\end{tabular}

It is possible to conclude that the crystallinity of the samples, maintains a very close value crystallinity, but lower than the pure LDPE. It can be concluded that this value was modified by the high 
concentration of SCBA particles and the NR in the samples, which originated the amorphous material with the obtained properties.

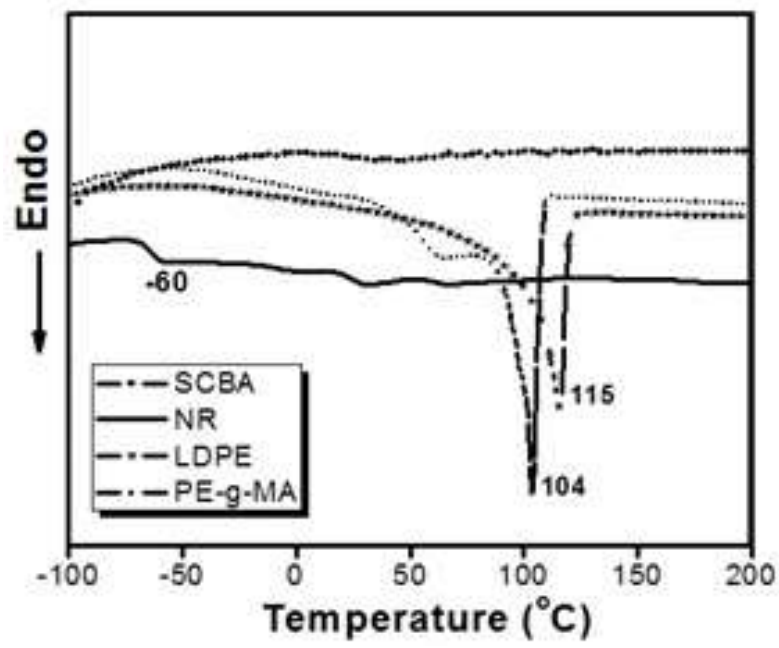

Figure 7: DSC Curves obtained of the materials before the mixing process.

The observed changes in the fusion peak stem from the difference in the percentage crystallinity of the samples; the relative size of the endothermic peaks may change [36] if the material has a high percentage of amorphous character, as for the NR mixed with inorganic particles as reinforcement.

The samples with $30 \%$ and $50 \%$ of NR showed a reduction in the enthalpy of fusion with the presence of graphitized polyethylene, which may mean that there was no restriction in the macromolecular chain, together with an improvement in the interaction of the phases, resulting at a displacement in the melting temperature[37] value of 115 to $112^{\circ} \mathrm{C}$.
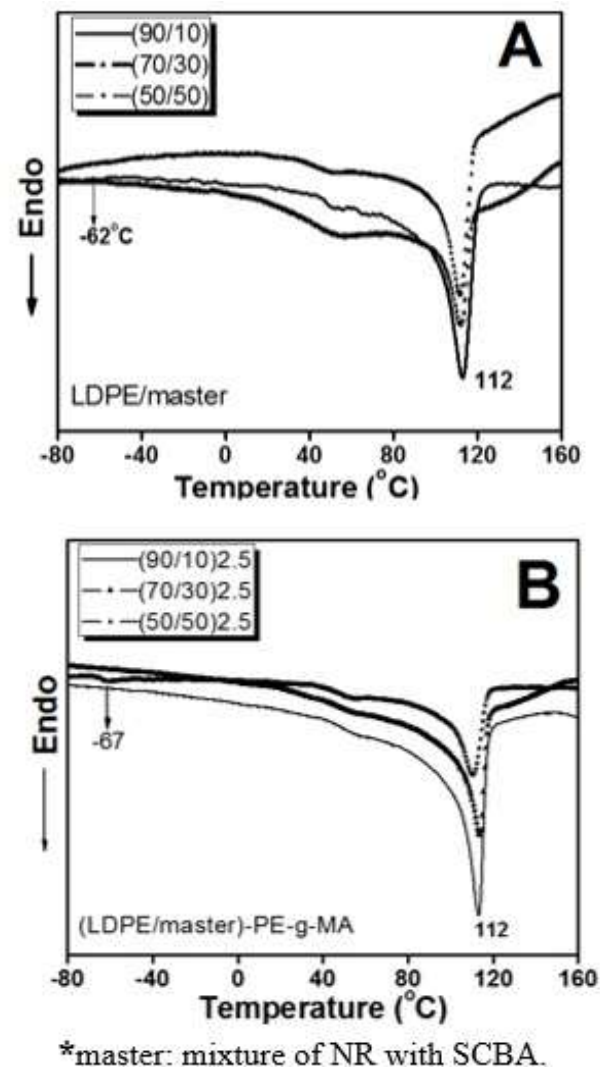

Figure 8: DSC curves of LDPE/master (A); (LDPE/master)-PE-g-MA (B). 


\subsection{Morphological characterization}

Figure 9 displays the SEM images of cross sections of the samples; image A, 90/10 (wt.\%) ; B, 70/30 (wt.\%); and C, 50/50 (wt.\%) of LDPE/master. Similarly, images A1, B1, and C1 correspond to LDPE/master-PE-g-MA samples.

In the images $\mathrm{A}, \mathrm{B}$, and $\mathrm{C}$ can be seen as a response to the fatigue fracture on the sample, which occurs because of the resistance of the cut material during stress. A similar response was observed by Ismail et al.,who analyzed the surface failure in thermoplastic elastomers[38]. Some areas with higher volume in the white sample correspond to the polyethylene phase in mixtures. Samples containing 50 (wt.\%) of the elastomer phase (images $\mathrm{C}$ and $\mathrm{C} 1$ ) showed similar behavior, without presenting the peaks of the specimens with higher LDPE content. Surface deformations decreases with reduction polyethlyene content due to the predominant plastic behavior over elastic behavior of natural rubber present in the samples.

In Figure 9, images A1, B1 and C1 correspond to mixtures without PE-g-MA. The images show a reduction in particle agglomerates and a more homogeneous surface compared to samples containing PEg-MA. The concentration of surface irregularities in the mixtures gradually increases with increasing LDPE content. This behavior confirms that the characteristics of the mixtures are directly related to the proportion of the thermoplastics present in the sample.
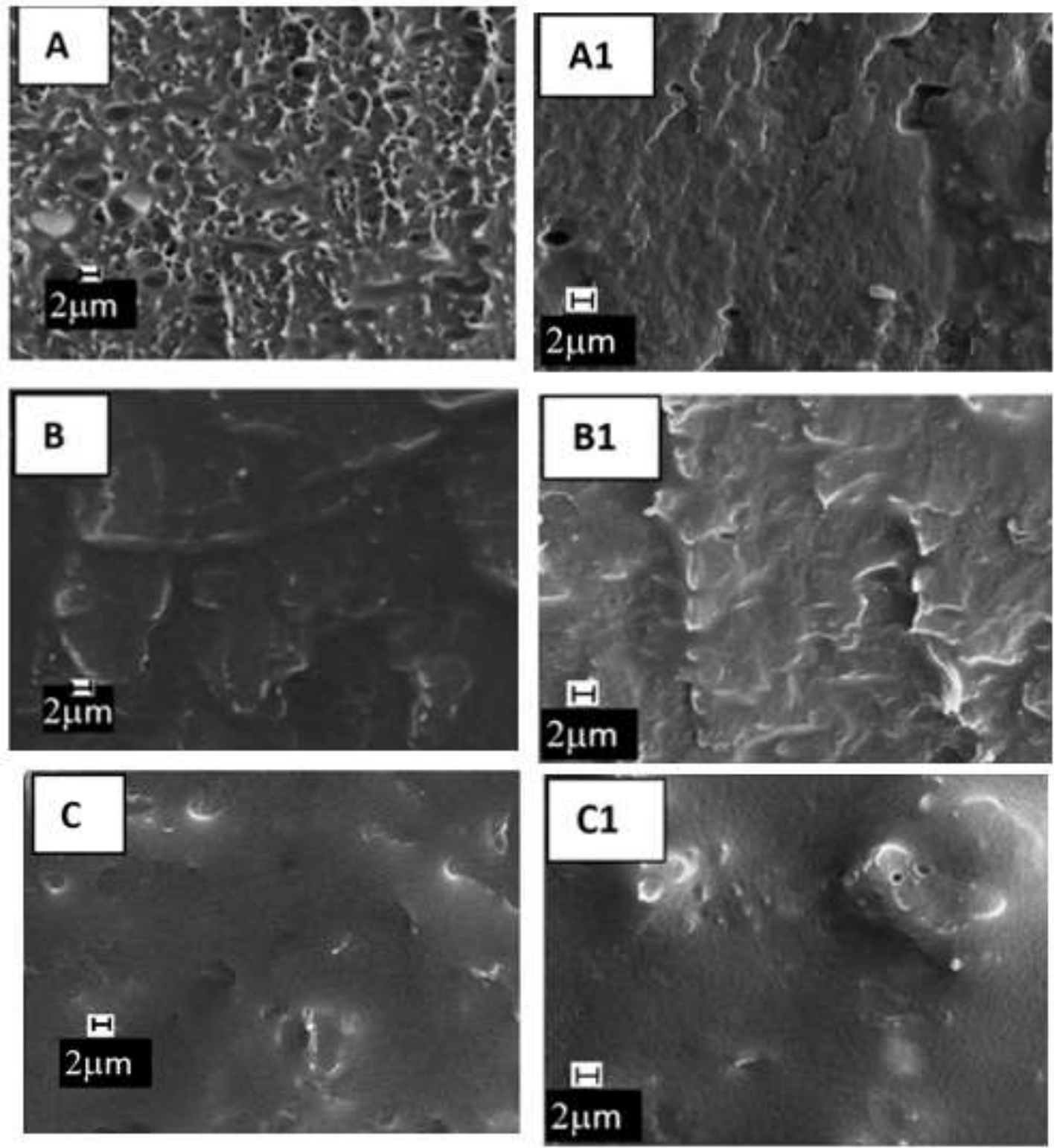

Figure 9: Scanning electron microscopy with 3000X magnification of the cross-sectional samples, A 90/10, B 70/30, C 50/50 (wt.\%) of LDPE/master)-PE-g-MA; and A1 90/10, B1 70/30, C1 50/50 (wt.\%) of LDPE/master. 


\subsection{Dynamic mechanical analysis}

Figure 10 shows the Tan $\delta$ curves for LDPE/master mixtures. The curves show a peak centered at $-21^{\circ} \mathrm{C},-26.1$ ${ }^{\circ} \mathrm{C}$, and $-21.4{ }^{\circ} \mathrm{C}$ for the 50/50, 70/30, and 90/10 (wt.\%) samples respectively. These peaks are related to the NR glass transition, which is shifted by the polymorphism of the mixture of SCBA and LDPE. It can be noted that the materials are less elastic than the pure rubber due to the presence of particles and strong interaction with the matrix, leading to reinforcement. This causes an increase in the elasticity modulus of the mixtures because of improved compatibility with the grafted polyethylene.
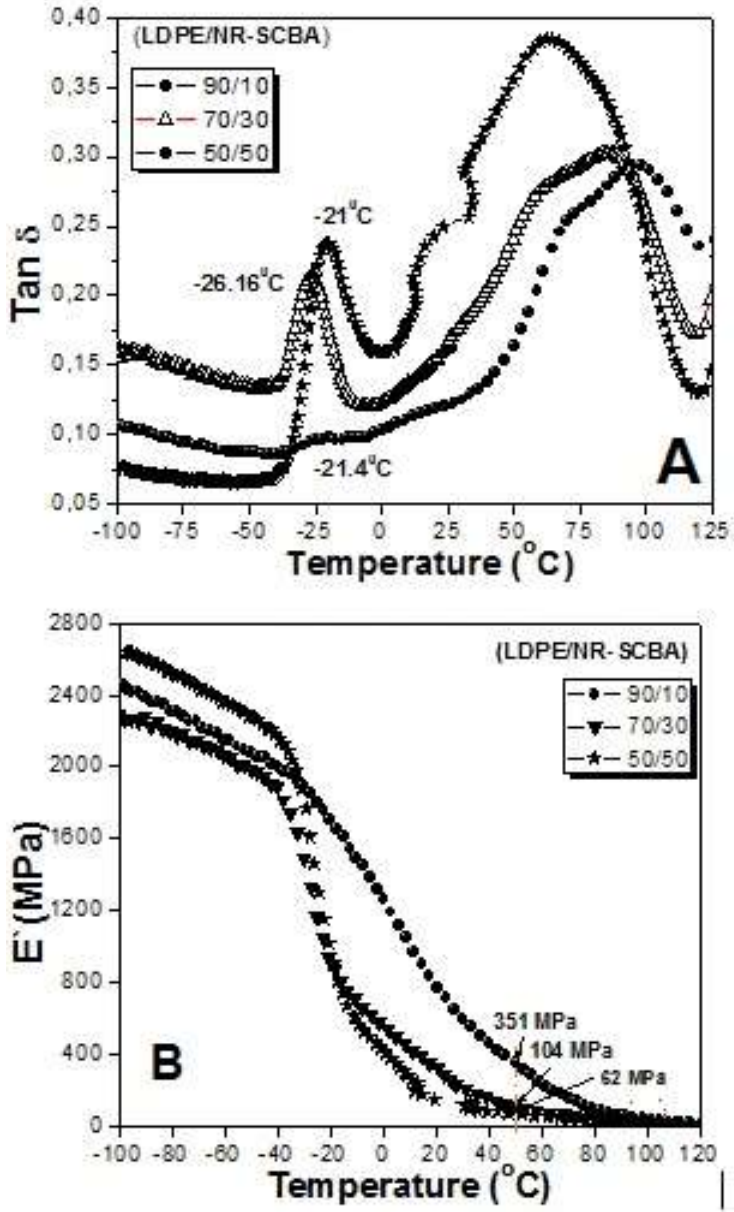

Figure 10: Image A corresponding curves to Tan $\delta$ and B image corresponding to storage module of mixtures (LDPE /master).

Figure 11 presents the curves generated to study the modulus of LDPE/master mixes. At low temperatures $\left(-100{ }^{\circ} \mathrm{C}\right.$ ), the blends had high energy storage modulus values. The 50/50 (wt.\%) thermoplastic elastomer showed the highest value because of the higher stiffness index achieved by the presence of equal amounts of NR and LDPE. The 70/30 and 90/10 (wt.\%) composites showed lower values as a result of a smaller proportion of NR in the mixture. The image B shows that the storage modulus decreases proportionally with the increase in temperature during analysis. At $60^{\circ} \mathrm{C}$, the values for the 90/10(wt.\%), 70/30(wt.\%), and 50/50 (wt.\%) samples were $243 \mathrm{MPa}, 87 \mathrm{MPa}$, and $61 \mathrm{MPa}$ respectively. The values were attributed to the prevalence of LDPE in the blend.

The obtained curves corresponding to the Tan $\delta$ of the LDPE/master-PE-g-MA mixture are shown in Figure 10, image A. The curves shows peaks at $-19{ }^{\circ} \mathrm{C},-21^{\circ} \mathrm{C}$, and $-21{ }^{\circ} \mathrm{C}$ for the $50 / 50$ (wt. \%), 70/30(wt. \%), and 90/10 (wt.\%) samples respectively. These peaks are related to the glass transition temperature of NR, which is shifted due to the polymorphism of the master mixture with SCBA and LDPE components. The presence of particles and the improved interaction with the matrix lead to an increase in the modulus of the mixtures.

The curve rises until the polyethylene melting temperature is reached, because the increased temperature results in greater disentanglement of the chains. At $50{ }^{\circ} \mathrm{C}$, the highest storage modulus is observed for the $90 / 10$ (wt.\%) sample and that for the LDPE/master mixture reaches $351 \mathrm{MPa}$. 

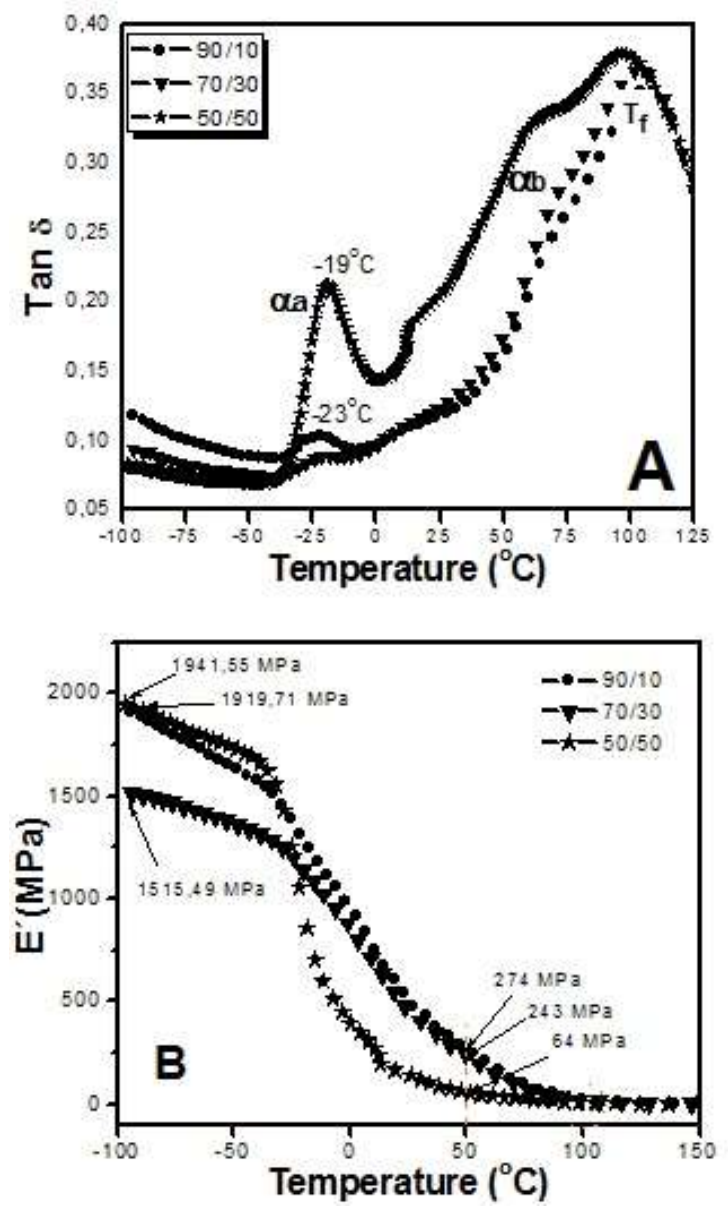

Figure 11: Image A. corresponding curves to Tan $\delta$ and B image corresponding to storage module of mixtures of blends (LDPE /master) -PE-g-MA.

The 70/30 (wt.\%) sample mixed with PE-g-MA gave the strongest system response of $243 \mathrm{MPa}$, while the $50 / 50$ (wt.\%) mixture gave a response of $64 \mathrm{MPa}$. These values were achieved due to the strong interaction between the constituent materials during physical mixing using the Haake rheometer.

\section{CONCLUSIONS}

Were demonstrated that the beneficial effects of improved interaction between the constituents apply PE-g-MA. The results showed that incorporation of the coupling agent PE-g-MA reduced the strain but improved the stress behavior and the module of the mixtures in presence of SCBA, were increased the hardness while maintaining the elongation behavior of the polymer. Was observed that the melting point of the blends were reduced by the addition of the coupling agent. By SEM analysis was observed that, the samples obtained good surface distribution of the SCBA particles throughout the matrix. Is possible to conclude that environmentally friendly blends, without vulcanization agents, can be used within the polymer industry because of the favorable mechanical and thermal properties afforded through optimization of additives, such as sugarcane residues and PE-g-MA.

\section{ACKNOWLEDGEMENTS}

The authors give special thanks to AIUP/PAEDEX-UNESP-ITM for financial support to the doctoral research, which gave rise to this publication. 


\section{BIBLIOGRAPHY}

[1] SATAPATHY, S., NAGB, A., NANDO, G. B., " Thermoplastic elastomers from waste polyethylene and reclaim rubber blends and their composites with fly ash", Process Safety and Environmental Protection, v.28, n.2, pp. 131-141, 2010.

[2] CALLISTER Jr.,W., Materials Science and Engineering: An Introduction, 5 ed., Rio de Janeiro., John Wiley and Sons, 2000.

[3] MCKEEN, W., LAURENCE, Thermoplastic elastomers, of the effect to temperature and other factors on plastics and elastomers, William Andrew Inc., pp. 419 - 420, Norwich, 2008.

[4] ONG, S.K., HASHIM, A. S., "Effect of polystyrene-modified Natural rubber as high molecular weight modifier in PP based binary blends", Int. J. of Eng. \& Technology, v.11,n 4, pp. 30-37, 2011.

[5] ELLUL, M. D., PATEL, J., TINKER, A. J., "Cross-link densities and phase morphologies in dynamically vulcanized tpes”, Rubber chemistry and technology,v.68, pp. 573 - 584, 1995.

[6] MISRA, D.J., ASHOK, D., Morphology property relations hips of Materials Properties to Structure , Lancaster, Technomic Publishing Company, Inc., pp. 68-70, 2000.

[7] COUTINHO, F. M. B., MELLO, I. L., SANTA MARIA, L. C., "Polietileno: Principais tipos, propriedades e aplicações”, Polímeros: Ciência e Tecnologia, v. 13, n 1, pp. 1-13, 2003.

[8] SCARAMUZZO, M., “Cenário positivo para o setor sucroalcooleiro”, em 2010/11. On line https://jornalcana.com.br/cenario-positivo-para-o-setor-sucroalcooleiro-em-201011, visit date, may 17, 2019.

[9] SANCHEZ, E. M. S., CAVANI, C. S., LEAL, C. V., et al, "Compósito de resina de poliéster insaturado com bagaco de cana de acúcar”, Polimeros, v. 20, n 3, pp. 194 - 200, 2010.

[10] SANTOS, L., MOACYR, L., OMAR, J., et al, "Estudo das condições de estocagem de bagaco de cana de açúcar por análise termica", Quimica Nova, v. 34, n 3, pp. 507 - 511, 2011.

[11] SALES, A., LIMA, S., Use of Brazilian sugarcane bagase ash in concret as sand remplazement, Wastemanagement, 2010.

[12] ROWELL, ROGER M., SANADI, A. R, et al., "Utilization of natural fibers in platic composites: problems and opportunities", Lignocellulosics plastics composites, Sao Paulo, USP-UNESP, pp. 29-31, 1997.

[13] FARIA, K. C. P., HOLANDA, J. N. F., "Incorporation of sugar bagasse ash waste as an alternative raw material for red ceramic", Cerámica, v. 59, n .351, pp. 473 480, 2013.

[14] PAULA, M. O., TINÔCO, F., ILDA, F., et al, "Potencial da cinza do bagaço da cana-de-açúcar como material de substituição parcial de cimento Portland", Revista Brasileira de Engenharia Agrícola e Ambiental, v. 13, n 3, pp. 353 - 357, 2009.

[15] TURMANOVA, S., GENIEVA, S., VLAEV, L., "Obtaining some polymer composites filled with rice husks ash a review", Canadian Center of Science and Education, 2012.

[16] OZÓRIO, M. S., REIS, E. A.P., TEIXEIRA., S.R., et al, "Sugarcane bagasse ash as a reinforcing filler in thermoplastic elastomers: structural and mechanical characterizations”, J. appl. polym. Sci., pp. 1-7, 2015

[17] SAE-OUI, P., RAKDEE, C., THANMATHORN, P., "Use of Rice Husk Ash as Filler in Natural Rubber vulcanizates”, Journal of Applied Polymer Science, v. 83, pp. 2485-2493, 2002.

[18] ISMAIL, H. F., HAW, S., "Effects of palm ash loading and maleated natural rubber as a coupling agent on the properties of pal ash filler natural rubber composites", Journal of Applied Polymers Science, v. 110, pp. 2867-2876, 2008.

[19] ZAKIR M. O., RZAYEV, "Graft copolymers of maleic anhydride and its isostructural analogues: high performance”, Engineering materials, International Review of Chemical Engeneering,v.3, pp.153-215, 2011.

[20] ZHOU, X., YU, Y., LIN, Q., et al., "Effects of maleic anhydride-grafted PP (Mapp)", Bioresources, v. 8, n. 4, pp. 6263-6279, 2013.

[21] FENG, L., NING, N.-Y., CHEN, L., et al, "Effects compatibilizers on the mechanical properties of lowdensity polyethylene-ligning blends", Chinese Journal of polymers Science, v. 27, n. 6 , pp. 833-842, 2009.

[22] LLOYD, M., R., "Reactive compatibilization of polymer blends: a Comprehensive Review", Munich, Hanser, 2007.

[23] GILES, H. F., GILES, F., HAROLD, R., et al, Processing conditions extrusion process of: The definitive processing guide and handbook, William Andrew, 2005 
[24] CHOUDHURY, N.R., BHOWMICK, A. K., S. K. Thermoplastic N.R. N. Rubber: Biology, Amsterdam, Elsevier, 1992.

[25] MARATHE, D. S., JOSHI, P. S., "Characterization of highly filled wood flour-PVC composites: morphological and thermal studies", J. of Appl. Pol. Science, v. 114, pp. 90-96, 2009.

[26] MINICK, J., A. MOET, BAER E., "Morphology of HDPE/LDPE blends with different thermal histories", Polymer, v. 36, pp. 1923-1932, 1995.

[27] MORSHEDIAN, J., MOHAMMAD, P., HOSEINPOUR, H. A., et al, "Effect of polymer structure and additives on silane grafting of polyethylene", Express Polymer Letters, v.3, n. 2, pp. 105-115, 2009.

[28] FENGWEI, X., XIEA, F., HALLEYA, P. J., et al., "Rheology to understand and optimize processibility, structures and properties of starch polymeric materials", Progress in Polymer Science, v. 37, pp. 595- 623, 2012.

[29] DUFRESNE, A., ABDELMOULEH, M., BOUFI A. S., et al., "Short natural-fibre reinforced polyethylene and natural rubber composites: Effect of silane coupling agents and fibres loading", Composites Science and Technology, v. 67, pp. 1627-1639, 2007.

[30] SHIEH,Y.-T., S., LIU, C.M. "Silane grafting reactions of LDPE, HDPE, and LLDPE", J. Appl. Polym. Sci., v. 74, pp. 3404-3411, 1999.

[31] MORSHEDIAN, J., HOSEINPOUR, P., MOHAMMAD, A., et al, "Effect of polymer structure and additives on silane grafting of polyethylene", Express Polymer Letters, v. 3, n. 2, pp. 105-115, 2009.

[32] SUPRI, A.G, TAN, S.J., ISMAIL, H., et al, "Properties of (Low-Density Polyethylene)/(Natural Rubber)/(Water Hyacinth Fiber) composites: The effect of polyaniline", Journal of Vinyl \& Additive Technology, pp. 122-130, 2014.

[33] SARIFUDDIN, N., ISMAIL, H., AHMAD, Z., "Studies of properties and characteristics of low-density polyethylene/thermoplastic sago starch-reinforced kenaf core fiber composites", Journal of Thermoplastic Composite Materials, DOI:10.1177/0892705713486125.11, 2013.

[34] APIPLASTIC. www.apiplastic.com. Visit date. April 21 of 2018.

[35] PISTOR, V., CHIESA, A., ZATTERA, A. J., "Study of the reprocessing of low density polyethylene reclycled from extruded blow films", Polymers, v. 20, pp. 269-274, 2010.

[36] WALLACE, J.G., In handbook of thermoplastic elastomers, pp. 143. E.M. Walker and C.P. Rader (Eds.),Van Hostred Reinhold, New York,1998.

[37] SOARES, B. G., SANTOS, D. M., SIRQUEIRA, A. S., "A novel thermoplastic elastomer based on dynamically vulcanized polypropylene/acrylic rubber blends", Express Polymer Letters, v. 2, n.8, pp. 602-613, 2008.

[38] ISMAIL, H., SURYADIANSY, A.H., "Thermoplastic elastomers based on pp/recycle rubber blends", Polymer Testing, v. 21, pp. 389-395, 2002.

\section{ORCID}

Giovanni Barrera Torres

Aldo Eloízo Job

Flávio Camargo Cabrera

Guilherme Dognani

Silvio Rainho Teixeira

Julio césar Alzate

https://orcid.org/0000-0002-0796-1096

https://orcid.org/0000-0002-1979-8257

https://orcid.org/0000-0001-7924-7089

https://orcid.org/0000-0002-6794-8440

https://orcid.org/0000-0002-5797-5971

https://orcid.org/0000-0001-9872-5509 